\title{
Measuring Innovative Thinking Skills in Innovation Challenge Activities
}

\section{Dr. Catherine T. Amelink, Virginia Tech}

Dr. Amelink is Director of Graduate Programs and Assessment in the College of Engineering, Virginia Tech.

\section{Ms. Christina Nocon Seimetz, Virginia Tech}

Christina Seimetz is a PhD student in the Department of Engineering Education at Virginia Tech. She also serves as program support staff for the Center for the Enhancement of Engineering Diversity where she is involved with recruitment, outreach, and retention programs specifically targeted towards females interested in engineering. Ms. Seimetz earned her B.S. in Mechanical Engineering and her M.S. in Biomedical Engineering from Virginia Tech.

\section{Dr. Bevlee A. Watford, Virginia Tech}

Mr. Joseph Ariel Cuadrado-Medina, Virginia Polytechnic Institute and State University

Joseph is a Graduate Student in the Mechanical Engineering and Nuclear Engineering departments at Virginia Tech in Blacksburg. While studying for his Master's Degree, he had the privilege of working at the Center for the Enhancement of Engineering Diversity (CEED) as a graduate assistant. In his time working at CEED, he became a co-director of inVenTs Studio $1 \& 2$ located in a residential hall on campus. There, he taught students how to use the equipment, facilitated company interactions to make Innovation Challenge Activities possible, and oversaw a group of upper-class undergraduates who help lead the community to success. He is a member of ANS, ASME, INMM, and IEEE.

\section{Mr. Juan Carlos Folgar-Lopez}

Dr. Stephanie Nicole Lewis, Virginia Tech 


\section{Measuring Innovative Thinking Skills in Innovation Challenge Activities}

\section{Introduction}

Several recent reports have highlighted the need for innovative thinking skills as the U.S. looks to maintain a viable national economy ${ }^{[1,2]}$. These skills include the ability to exercise innovative and entrepreneurial thinking skills ${ }^{[3,4]}$.

When considering the body of literature that surrounds the development of innovative thinking skills among engineering undergraduates, several studies provide a framework that creates the program's living-learning experience. Literature has attempted to highlight skills that innovative engineering undergraduates would demonstrate ${ }^{[3-5]}$. Using problem-solving methodologies and a variety of corporate based literature as references, engineering educators suggest that students would be able to set goals for their own learning and identify when they need to seek new knowledge to solve problems. Innovative thinkers should be able to give and receive feedback on new ideas as well as possess the ability to represent those ideas visually and contextually. Students should also be able to think critically so that they can assess the value of their prior knowledge and elaborate, translate, and summarize known and new information ${ }^{[6-8]}$. Activities that have students use concepts in new and different contexts such as those provided by openended problems that need to be solved and then sharing that information with others for critical feedback can help develop innovative thinking ${ }^{[9-11]}$.

Research has shown that out of class activities can play an important role in reinforcing what students are learning in the classroom and provide opportunities for collaborative learning with peers and faculty. These organized activities can further reinforce learning and provide opportunities to apply known information in new contexts ${ }^{[12]}$. Specifically, themed living learning communities (LLCs) at the undergraduate level play a role in promoting skill development among students enrolled in engineering programs. For instance, students who participate in LLCs have also shown greater learning and developmental gains in the areas targeted for enrichment when compared to peers who have not selected to participate in these activities $^{[13]}$.

Efforts are being made to encourage the development of innovative and entrepreneurial thinking in undergraduate science and engineering students through a multidisciplinary living-learning program. Based then on what is known about the development of innovative thinking, in addition to what is currently offered in the way of academic and social support, participants in the livinglearning community have the chance to engage in hands-on activities that are designed to encourage and develop innovative thinking. Residents are involved in activities that allow for direct involvement in the full chain of innovation from research and transition to translation and commercialization.

Linked to the activities being offered in this residential community, our research is examining what curricular and co-curricular initiatives have been shown to develop students' ability to be innovative. Quantitative and qualitative methods being employed include student surveys, focus groups, and direct methods of observation of skills demonstrated during design competition. Results related to this research will share the best practices identified and resources that can help 
educators in teaching innovation, while at the same time encouraging success among engineering undergraduates. This paper reports on the assessment efforts linked to two weekend design competitions that were offered to program participants. Using different topics, the competitions have provided students with problem-based learning opportunities and the chance to design solutions through hands-on applications and resources provided to students.

\section{Innovation Challenges}

To promote innovation, the living-learning program provides Innovation Challenges in which students learn about real-world applications of innovation and entrepreneurship through the completion of small, hands-on design challenges. Company representatives often lead the Innovation Challenges, in which they provide information about their company and jobs and then facilitate a design challenge that is typically based on a company product or project in a three to four hour workshop setting. In the Fall semester of 2013, two consulting companies sponsored Innovation Challenges for program participants.

\section{Company 1}

Representatives from Company 1 split the event into an introductory portion and then the main design competition. The introduction allowed participants to become acquainted with each other through a small-scale construction activity. Students were broken into groups and provided with a variety of materials, from which they were told to construct the tallest tower possible. It is important to note that each team had different materials and the purpose of the activity was to get the students thinking outside of standard competition norms, since they could have easily paired up as a conglomeration of teams to combine resources. The goal of the follow-up design activity to create a medical app for mobile devices. Using the company's consulting framework of brainstorming solutions for issues and bringing them to fruition through consultations with the customers and technical experts, the students formed their ideas into proposals that were then presented to the company representatives.

\section{Company 2}

During this Innovation Challenge, the hosting company introduced students to project development and consultation. Participants learned about comprehensive consulting practices, including establishing the parameters of a contract and handling changes to the project requested by the customer. During the activity, participants simulated the consulting process. Pairs of students were tasked with interviewing potential customers to gather information pertaining to the building of a yacht. After the interview period, the representative evaluated the students' interview skills and informed them of any additional considerations that would be needed for consulting on such a project. To incorporate design, participants were then tasked to build a prototype of the yacht with a standard set of requirements. Items to be used were priced by the representatives and students were evaluated on the total cost of their yacht. The integrity of each boat was tested in a tub of water, where each yacht prototype should be able to hold a small collection of pennies. The boat with the least building costs and greatest weight capacity was considered to be the best design. 


\section{Methodology}

Participants

Students that participated in the Innovation Challenges were science and engineering undergraduates from the living-learning program. The number of participants was determined by the capacity of the physical space in which the event was held, as well as preference by the hosting company. Participation was also limited by major; in order to best-represent the entire population of the living-learning program, a predetermined number of students from each major could participate in the events. Innovation Challenges were announced to all members of the living-learning program. Members that were interested in participating were asked to complete a survey, providing their contact information. Based on the criteria above, participants were chosen on a first-come, first-serve basis.

\section{Instrumentation}

An observation rubric was used to assess participants' innovative thinking skills during the Innovation Challenges. Various components of innovative thinking have been characterized in the literature surrounding innovation ${ }^{[3-8]}$. Skills that highlight innovative thinking chosen as criteria for the rubric to capture the different stages of innovation (See Table 1). A scoring key was used to rate the level of innovative skill development (Not Observed $=0$; Below Average $=$ 1; Average $=2$; Above Average $=3$; Not Applicable $=$ NA) among participants .

An online survey was used to obtain feedback about each Innovation Challenge. After the event, participants were asked to rate the degree to which the competition impacted innovative thinking skills. These questions ask them whether participating in these activities have enhanced key innovative skills as proposed by Zheng ${ }^{[11]}$. Participants were given an opportunity to provide information about what they enjoyed most and what they found most frustrating about the activity.

\section{Data Collection}

During design activities, participants were typically broken into groups. Event facilitators observed teams of participants during the event and used the rubric score teams on innovative thinking skills demonstrated during the design activity. The reviewers met prior to the competition to establish common expectations for what might be observed among students and how they would score the range of different skills they might observe. After rating the students, the reviewers met again to discuss how they rated participants and provided justification based on field notes as to why those teams were scored accordingly. Any discrepancies in scoring were resolved during this discussion. This process was used to establish inter-rater reliability. An observation rubric was completed for each group. Finally, the post-event survey was sent to participants after each event.

\section{Data Analysis}

Rubric scores were tallied and averaged across reviewers for each team for each team and then an overall average across teams was computed. Mean scores on each item in the survey were tallied to provide an overall score for each question among respondents. 


\section{Results}

In total 33 students participated in two competitions offered in Fall 2013. Evaluators made observations of all participants during each Innovation Challenge. In addition, 24 students responded to the online post-event survey, which sought to determine what innovative thinking skills students thought that they demonstrated during the event.

\section{Observations of Innovative Thinking Skills}

Participants were observed by activity facilitators during the design activities. Table 1 shows each team's average score for each stage of innovation, as well as an overall rating of innovative thinking demonstrated during the competition. Table 1 also shows an average score for each skill across both activities. Results from the observations show that communication skills were most strongly demonstrated by teams during the activity hosted by Company 1, while critical thinking and ideation were most strongly demonstrated in the activity hosted by Company 2 . In contrast, teams received lower scores in application and integration of knowledge and complex thinking processes during the activity hosted by Company 1 and in communication skills ad complex thinking in the activity hosted by Company 2. Overall, the teams in both activities strongly demonstrated critical thinking, ideation, and effective use of technology.

Table 1. External Observation of Stages of Innovation Among Competition Participants

\begin{tabular}{|c|c|c|c|}
\hline \multirow{2}{*}{ Skill } & \multicolumn{3}{|c|}{ Mean Observation Scores } \\
\hline & Company 1 & Company 2 & Overall Mean \\
\hline $\begin{array}{l}\text { Demonstrates critical thinking and effective generation of } \\
\text { new ideas }\end{array}$ & 2.0 & 2.8 & 2.4 \\
\hline $\begin{array}{l}\text { Demonstrates application and integration of } \\
\text { science/engineering content knowledge }\end{array}$ & 1.9 & 2.3 & 2.1 \\
\hline $\begin{array}{l}\text { Demonstrates ability to organize new } \\
\text { information/ideas/products in an understandable way }\end{array}$ & 2.3 & 2.3 & 2.3 \\
\hline $\begin{array}{l}\text { Demonstrates ability to communicate ideas to peers, faculty, } \\
\text { and potential industry representatives in presentation }\end{array}$ & 2.5 & 2.0 & 2.3 \\
\hline $\begin{array}{l}\text { Demonstrates effective use of technology/tool selection in } \\
\text { design process }\end{array}$ & 2.3 & 2.5 & 2.4 \\
\hline $\begin{array}{l}\text { Demonstrates complex thinking process that transforms a } \\
\text { creative idea into useful services/products }\end{array}$ & 1.9 & 2.0 & 2.0 \\
\hline Demonstrates potential for prototyping/commercialization & 2.0 & 2.3 & 2.2 \\
\hline TOTAL & 14.9 & 16.2 & 15.6 \\
\hline
\end{tabular}

Student Self-Assessment of Innovative Thinking Skills

Students participating in the activities indicated that they had a positive impact on their innovative thinking skill development. Responses indicated that the activities allowed them to develop new solutions and also allowed them to apply knowledge in new and different ways. Overall, participants from the event hosted by Company 2 reported that the activity had a higher impact on their innovative thinking skill development than the participants from the activity hosted by Company 1. 
Table 2. Results of Student Self-Assessment $(n=24)$

\begin{tabular}{|l|c|c|c|}
\hline \multirow{2}{*}{ Question } & \multicolumn{3}{|c|}{ Mean Scores } \\
\cline { 2 - 4 } & Company 1 & Company 2 & Overall Mean \\
\hline $\begin{array}{l}\text { Participating in this activity helped me think about things I } \\
\text { already knew in new and different ways. }\end{array}$ & 3.62 & 4.13 & 3.87 \\
\hline $\begin{array}{l}\text { Participating in this activity allowed me to test out different ideas } \\
\text { to see if they would work. }\end{array}$ & 3.54 & 4.00 & 3.77 \\
\hline $\begin{array}{l}\text { Participating in this activity allowed me to generate new } \\
\text { solutions, processes, and ideas. }\end{array}$ & 3.77 & 4.13 & 3.95 \\
\hline $\begin{array}{l}\text { Participating in this activity helped me make connections } \\
\text { between solutions and ideas being generated and how they could } \\
\text { be applied to solve other problems. }\end{array}$ & 3.69 & 4.00 & 3.84 \\
\hline $\begin{array}{l}\text { Participating in this activity allowed me to think about how to } \\
\text { commercialize the ideas, processes, or solutions generated. }\end{array}$ & 3.55 & 4.38 & 3.96 \\
\hline
\end{tabular}

Responses from open-ended questions indicate that students enjoyed the activities but also enjoyed learning about consulting as a career in an engineering field through interaction with current company employees. For both Innovation Challenges, participants reported that they liked being able to work on a real-world problem through a hands-on activity. Students particularly enjoyed working in groups for the activity sponsored by Company 1 . Those that participated in the activity sponsored by Company 2 liked that the activity encompassed more than just the design aspect of consulting. One student stated, "It was great to have a simulation that encompassed the complete process of a design including conversations with the client, budget, material troubles, testing and presentation. It was very fun and hands-on." Participants provided a few suggestions for improvement in the activities. Generally, students thought that both events were too long and could have been better organized.

\section{Discussion}

This paper reports efforts to assess innovative thinking in undergraduate students during two design-based activities offered by a multidisciplinary living learning community. Overall, students enjoyed the hands-on activities and learning about industry from company representatives. The Innovation Challenges utilized problem-based learning to engage students with the material at hand. Research suggests that problem-based learning enhances learning outcomes $^{[14]}$. Furthermore, interaction with and facilitation by company representatives may encourage and motivate students, as they see more value in the work than when the activity is directed by a faculty member. In particular, the team of representatives from Company 2 included a graduate from the university at which the Innovation Challenges were held. This could also add value to the activity because it provides a tangible example of the potential success awaiting them upon graduation.

Observational and self-assessment scores of innovative thinking were higher for the Innovation Challenge hosted by Company 2. This could be attributed to various characteristics of the activity. Firstly, students reported that they enjoyed experiencing more than just the design aspect of consulting. This activity was designed to allow students to gain experience with the 
entire consulting process, including customer relations, customer needs, and product design. This activity allowed to students to gain in a broader knowledge of the consultation experience and the opportunity to demonstrate their skills outside of the design process. In addition, students may find more value in the activity when experiencing the entire process of a real-world problem rather than just one aspect.

Based on our findings, we identified key characteristics of the Innovation Challenges that helped students gain the most out of the experience. Firstly, the use of hands-on, problem-based activities allowed students to interact with and think critically about the problem at hand. Students seemed to be especially engaged when the problem has or is related to a tangible, realworld application. Allowing students to work in groups helped to develop their teamworking skills and helped with ideation. In addition, students appreciated the opportunity to learn about and experience an entire process, such as in consulting, rather than just focusing on the design aspect of the process. Finally, students seemed to be more engaged when the activity is facilitated by a professional who has experience in the field. Students especially appreciate having a graduate from the program in which they are studying, as it reassures their education and career choices and provides evidence of success.

\section{Conclusions}

This paper reports current efforts of the assessment of innovative thinking skills in undergraduate students. We are currently assessing innovative thinking skills through observations during design activities and self-perception of skill demonstration after the activity. Observations provide a direct assessment of innovative thinking skills, as external observers rate the development and demonstration of innovative thinking skills in undergraduates while participating in a design activity. After the activity, students are asked to self-report the extent to which they felt that they demonstrated innovative thinking skills during the activity, as well as give feedback about the activity to provide insight on how to improve design activities in the future. As demonstrated by the results of the assessment described, design-based activities provide students with the opportunity to develop and demonstrate their innovative thinking skills.

\section{References}

1. Atkinson, R. and S. Andes. The Atlantic Century: Benchmarking EU and US Innovation Competitiveness. 2009 [cited 2013; Available from: http://www.itif.org/publications/atlantic-century-benchmarking-eu-and-usinnovation-and-competitiveness.

2. Lechletier, J., America's Growing Innovation Gap, in Wall Street Journal. 2009, Dow Jones and Company: New York, NY.

3. Pappas, E. Cognitive Processes Instruction in an Undergraduate Engineering Design Course Sequence. in American Society for Engineering Education. 2009. American Society for Engineering Education.

4. Raviv, D. and D.F. Barbe. Ideation to Innovation(I 2 I) Workshop. in American Society for Engineering Education. 2010. American Society for Engineering Education.

5. Jonassen, D., T. Mayes, and R. McAleese, A manifesto for a constructivist approach to uses of technology in higher education, in Designing environments for constructive learning. 1993, Springer. p. 231-247.

6. Lafer, S. and A. Markert, Authentic learning situations and the potential of Lego TC Logo. Computers in the Schools, 1995. 11(1): p. 79-94. 
7. Lehrer, R., Authors of knowledge: Patterns of hypermedia design. Computers as cognitive tools, 1993: p. 197227.

8. Pintrich, P.R. and T. Garcia, Student goal orientation and self-regulation in the college classroom. Advances in motivation and achievement: Goals and self-regulatory processes, 1991. 7(371-402).

9. Larwin, K. and D. Larwin, A Meta-Analysis Examining the Impact of Computer-Assisted Instruction on Postsecondary Statistics Education: 40 Years of Research. Journal of Research on Technology in Education, 2011. 43(3): p. 253-278.

10. McLellan, H., Interactions of student partners in a high school astronomy computer lab. Computers in the Schools, 1995. 11(1): p. 29-42.

11. Zheng, W., A social capital perspective of innovation from individuals to nations: where is empirical literature directing us? International Journal of Management Reviews, 2010. 12(2): p. 151-183.

12. Pascarella, E.T. and P.T. Terenzini, How College Affects Students: A Third Decade Of Research (Jossey-Bass Higher \& Adult Education) Author: Ernest T. Pas. 2005.

13. Kahveci, A., S.A. Southerland, and P.J. Gilmer, Retaining Undergraduate Women in Science, Mathematics, and Engineering. Journal of College Science Teaching, 2006. 36(3): p. 34-38.

14. Prince, M., Does active learning work? A review of the research. Journal of engineering education, 2004. 93(3): p. 223-231. 